\title{
CUMITHERM®- A State-of-the-art Zero Expansion Ceramics and its Applications
}

\author{
Santanu Mandal, Suresh Kumar Chatakonda, \\ Arijit Chatterjee and Shyam S Rao* \\ Carborundum Universal Limited, 47 \& 48 \\ 635126 Hosur, Sipcot Industrial Complex, India
}

Received 19.06.2017, received in revised form 09.09.2017, accepted 26.11.2017

Carborundum Universal Limited - Industrial Ceramic (CUMI - IC) Division design, develop, manufacture and supplies technical ceramic products for industrial applications. The applications include wear-resistance, corrosion-resistance, electrical insulation, dielectrics, thermal and thermal shock resistance, ballistic protection etc. CUMI-IC division has recently developed through in-house $R \& D$ and launched CUMITHERM ${ }^{\circledR}$ which is a reaction-sintered aluminium titanate $\left(\mathrm{Al}_{2} \mathrm{TiO}_{5}\right)$ products for thermal and thermal shock resistance applications. CUMITHERM ${ }^{\circledR}$ has near-zero/negative coefficient to thermal expansion, non-wettability to molten metal, excellent thermal insulation and very good mechanical and thermo-mechanical properties in this class of material.

The mechanical performance improves with increase in temperature and gets double data round $900{ }^{\circ} \mathrm{C}$. The unique properties like dimensional stability over a wide range of temperature and increase in strength with temperature are very rare in the field of material science. The reactions in tered aluminium titanate phases achieved by combining high-purity alumina and titania along with appropriate stabilizing agent and sintering additives in a precision controlled reactions in tering process and engineering a micro-fissures microstructure. Therefore, CUMITHERM ${ }^{\circledR}$ is ideally suited for non-ferrous molten metal handling and conveying applications like molten metal handling, conveying and in cast-house for primary processing of aluminium metals and secondary processing like non-ferrous foundries. The castings pouts and control rods, retainer rings,nozzles, launders, thimbles, dosing tubes, tapping plug and rings, insulation rings, riser tubes, sprue-bushes etc. Are the few example of CUMITHERM ${ }^{\circledR}$ application. CUMI has patent on a high-performance special designed $\mathrm{Al}_{2} \mathrm{TiO}_{5}$-tile lined launders products for non-ferrous cast-houses. The key benefits to the user sare (a) longer service life, (b) energy efficiency, (c) increased process reliability, (d) down-time reduction for reduced maintenance and (e) high-quality of process sed metals.

Keywords: AluminiumTitanate, ceramic products, thermal shock resistance.

(C) Siberian Federal University. All rights reserved

* Corresponding author E-mail address: mandalsantanu@cumi.murugappa.com 


\title{
CUMITHERM®- современная керамика с нулевым расширением и ее применение
}

\author{
Сантану Мандал, Суреш Кумар Чатаконда, \\ Арижит Чаттержи, Шиям С Рао \\ Карборундум Юниверсал Лимитед, $47 \& 48$ \\ Промылиленный комплекс Сипкот, Хосур - 635 126, Индия
}

Карборундум Юниверсал Лимитед - Подразделение Промымленной Керамики (CUMI - IC) проектирует, разрабатывает, производит и поставляет продукиию из технической керамики для промышленного применения. В область применения решений данного подразделения входят износостойкие, коррозионно-устойчивые, электроизоляиионные, диэлектрические, термоустойчивые и устойчивые к термическим ударам, баллистическая защита и т.д. Подразделение CUMI - IC, благодаря внутреннему отделу разработок, представило CUMITHERM ${ }^{\circledR}$, являющийся реакиионно-спечённым титанатом алюминия ( $\left.\mathrm{Al}_{2} \mathrm{TiO}_{5}\right)$, применяемый в условиях, требующих термической устойчивости либо устойчивости к термическим ударам. СUМITHERM ${ }^{\circledR}$ обладает околонулевым/отрицательным коэффициентом термического расширения, несмачиваемостью по отношению к расплавленному металлу, отличными теплоизоляционными свойствами, а также очень хорошими механическими u термомеханическими свойствами среди материалов данного класса. Механические характеристики улучшаются при увеличении температуры, удваиваясь при $900{ }^{\circ} \mathrm{C}$. Такие уникальные свойства, как геометрическая стабильность при широком диапазоне температур, а также увеличение прочности с увеличением температуры, очень редки в области материаловедения. Фаза реакционно-спечённого титаната алюминия достигается сочетанием сверхчистого глинозёма и титана при наличии подходящего стабилизирующего агента и спекающих добавок в точно контролируемой реакиии процесса спекания, а также микроструктуры, содержащей микротрещины. В связи с этим CUMITHERM ${ }^{\circledR}$ идеально подходит для обращения и транспортировки расплавленных иветных металлов в литейных цехах во время первичной переработки алюминия, как и вторичной переработки, например, в литейных иехах ияветных металлов. Сливные носки и регулирующие стержни, фиксаторы, разливочные стаканы, желоба, втулки, дозирующие трубки, выпускающие затворы и кольца, изоляционные кольца, подъёмные трубки, литниковые втулки и т.д. всего лишь малая часть примеров применения CUMITHERM ${ }^{\circledR}$. CUMI запатентовали специиально спроектированную высокопроизводительную литейную продукиию, футерованную плитами на основе $\mathrm{Al}_{2} \mathrm{TiO}_{5}$ для литейных цеехов иветной металлургии. Ключевыми достоинствами для пользователей станут (а) более высокий срок службы, (б)энергоэффективность, (в) увеличение надёжности процесса, (2) уменьшение времени простоя во время плановых ремонтных работ и (д) высокое качество производимых металлов. 
Ключевые слова: титанат алюминия, керамическая продукичя, устойчивость к термическим ударам.

\section{Introduction}

Zero thermal expansion ceramics is of importance in structural application due to its dimensional stability and hence stress-free characteristics under repeated thermal cycles. Aluminium Titanate (AT) has zero or negative thermal expansion coefficient over a broad range of temperature. The near-zero/ negative thermal expansion is attributed to its thermal hysteresis arises due to its thermal anisotropy during heating $\&$ cooling. The near-zero/negative coefficient of thermal expansion coupled with low thermal conductivity and good chemical resistance renders aluminium titanate $\left(\mathrm{Al}_{2} \mathrm{TiO}_{5}\right)$ as a sui Table material for diversified thermal and thermal shock resistance applications. The thermal hysteresis creates micro-fissure in the microstructure of aluminium titanate ceramics. The micro-fissures accommodate subsequent expansion due to heating and make it dimensionally sTable upon repeated heating and cooling process. This phenomenon exhibits few wonderful properties in aluminium titanate ceramics such as thermal shock resistance, low thermal conductivity, increasing strength with increase in temperature and non-wettability to most of the non-ferrous metals. These combinations of unique properties make aluminium titanate ceramics a high-potential candidate for structural applications. Therefore aluminium titanate based CUMITHERM ${ }^{\circledR}$ products are used extensively in non-ferrous metal holding, conveying and other applications which is described in detail subsequently.

\section{Structure and phase diagram}

Aluminium Titanate is isomorphous with pseudobrookite structure with orthorhombic unit cell with each $\mathrm{Al}^{3+}$ or $\mathrm{Ti}^{4+}$ cation surrounded by six oxygen ions forming distorted oxygen octahedra. These $\mathrm{AlO}_{6}$ or $\mathrm{TiO}_{6}$ octahedra form (001) oriented chains weakly bonded by shared edges [1, 2]. Such a structure is responsible for the thermal expansion anisotropy.

CUMITHERM ${ }^{\circledR}$ which is a ceramic material consisting of alumina $\left(\mathrm{Al}_{2} \mathrm{O}_{3}\right)$ and Titania $\left(\mathrm{TiO}_{2}\right)$ forming solid solution of $\mathrm{Al}_{2} \mathrm{O}_{3} \cdot \mathrm{TiO}_{2}$ or $\mathrm{Al}_{2} \mathrm{TiO}_{5}$ in stoichiometric proportion. It is prepared by sintering a mixture of alumina and Titania at a very high temperature in atmosphere with controlled oxygen partial pressure. Pure AluminiumTitanate is unsTable at a temperature in the range of $750-1250{ }^{\circ} \mathrm{C}$ when the solid solution decomposes following a eutectoid reaction into two separate phases, $\mathrm{Al}_{2} \mathrm{O}_{3}$ and

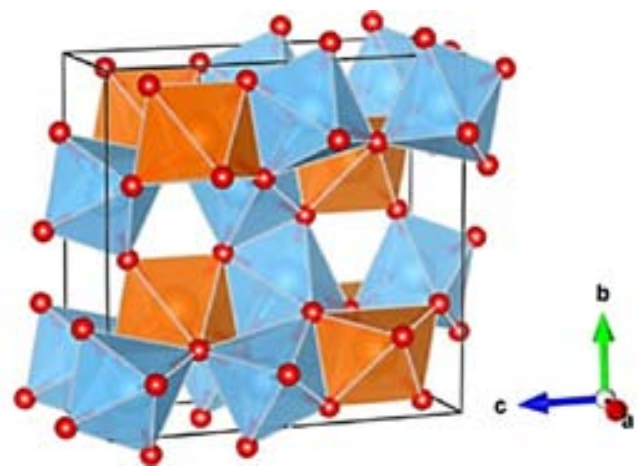

Fig. 1. Crystal structure of pseudobrookite-type compound [3] 


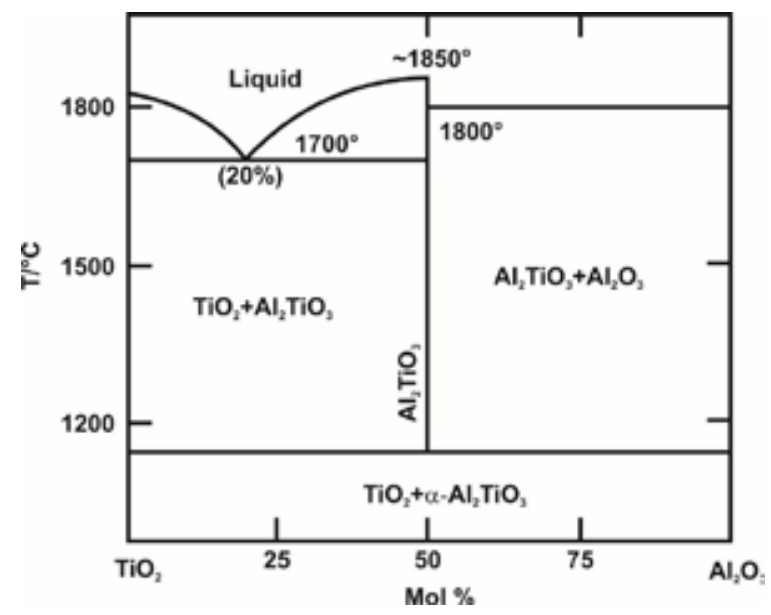

Fig. 2. $\mathrm{Al}_{2} \mathrm{O}_{3}-\mathrm{TiO}_{2}$ phase diagram as proposed by Goldberg (1968) [9]

$\mathrm{TiO}_{2}$. For this reason AluminiumTitanate ceramics are doped usually with certain additives [4-8] in order to stabilize the solid solution structure.

In CUMITHERM ${ }^{\circledR}$, appropriate additive has been used to stabilize the Al-titanate phase. One mole of Alumina reacts with one mole of Titania under certain condition to form aluminium titanate which undergoes reversible decomposition into alumina \&Titania as per the reaction below:

$$
\mathrm{Al}_{2} \mathrm{O}_{3}+\mathrm{TiO}_{2} \rightleftarrows \mathrm{Al}_{2} \mathrm{TiO}_{5}
$$

\section{Role of Additives in stabilization of AT Phase}

However, the major challenge is to stabilize aluminium titanate phase for a longer duration over the range of its application temperature as it undergoes reversible decomposition destroying its unique characteristics. Certain additives mentioned in the literature [4-8] are used to stabilize the aluminium titanate phase as well as to facilitate its sintering. Usually, the additives may either form liquid-phase or may promote solid state sintering through solid-solution formation maintaining the Hume-Rothery rule [10].

Since different electrovalence between cations of additives and $\mathrm{Al}^{3+}$ or $\mathrm{Ti}^{4+}$ results in numerous passages for solid-state reaction and promotes the process of sintering, additives with different electrovalences and different cation radii show remarkable difference in calcination process. Thus the bulk density of ceramics is usually improved during sintering process. For example, the cation radius of $\mathrm{Mg}^{2+}$ is about $0.057 \mathrm{~nm}$, which is similar to the cation radius of $\mathrm{Al}^{3+}(0.054 \mathrm{~nm})$; the cation radii of $\mathrm{Si}^{4+}$ and $\mathrm{Fe}^{3+}$ are $0.026 \mathrm{~nm}$ and $0.064 \mathrm{~nm}$, respectively.

In the aluminium titanate based products, the phase composition can be customized (either alumina-riched or titania-riched) keeping in mind the requirements of its application.

\section{Manufacturing Process}

Aluminium Titanate based CUMITHERM ${ }^{\circledR}$ products are produced through advanced ceramic manufacturing process (Fig. 3) such as usage of controlled purity raw material along with proprietary 
sintering additives, deflocculants, defoaming agents and certain organic binder system followed by ball milling, slurry preparation for spray-drying, iso-static/bi-axial pressing or slurry casting process followed by controlled firing process to facilitate the desired phase composition. The partial pressure of oxygen determines the formation and stability of aluminium titanate phase and it is controlled to develop desired phase in CUMITHERM ${ }^{\circledR}$ products.

Appropriate proportion of raw materials such as high purity alumina, titania, phase stabilizing agent, sintering additives and other organic raw materials for the preparation of dispersed slurry are weighed and processed as per the flowchart as below. The exacting proportion and amount of temporary organic binder system is also added during the slurry preparation stage.

\section{Properties of CUMITHERM}

In fact, CUMITHERM ${ }^{\circledR}$ is a unique material having good mechanical strength along with good thermal insulation. Again, due to its chemistry \& unique microstructure, CUMITHERM ${ }^{\circledR}$ maintains high contact angle $\&$ hence has an exceptional non-wettability against non-ferrous molten metal. The properties of reaction-sintered aluminium titanate product are mentioned in the Table 1.

As discussed earlier, the above properties are achieved by combining High Purity Alumina and Titania in a precision controlled reaction sintered process to engineer a micro-porous microstructure in CUMITHERM ${ }^{\circledR}$ products. Therefore, it is an ideally suited product for Non Ferrous metal handling,

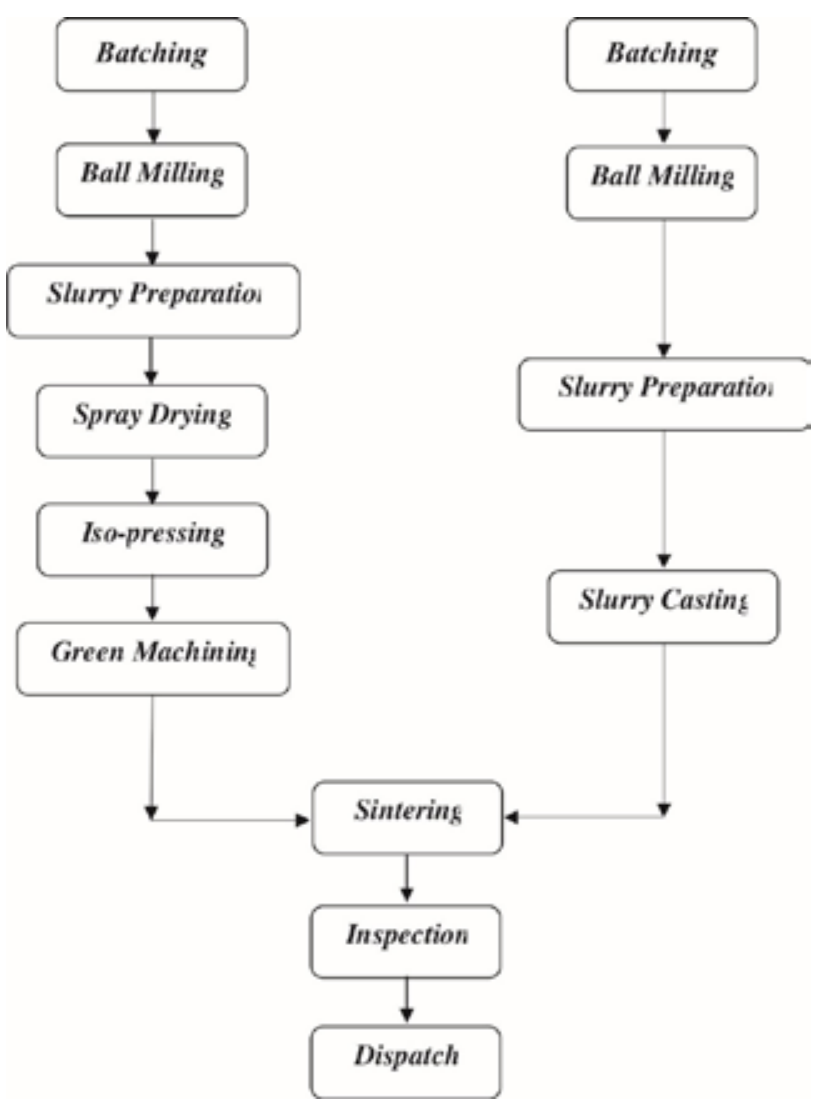

Fig. 3. Process Flowchart 
Table 1. Properties of CUMITHERM ${ }^{\circledR}$

\begin{tabular}{|l|c|c|}
\hline \multicolumn{1}{|c|}{ Attributes } & Unit & Value \\
\hline Bulk Density & $\mathrm{g} / \mathrm{cc}$ & 3.25 \\
\hline$\%$ Apparent Porosity & $\%$ & 8.0 \\
\hline Coefficient of Thermal Expansion & $10^{-6} /{ }^{\circ} \mathrm{C}$ & $\sim 0.00$ \\
\hline Flexural Strength at RT & $\mathrm{MPa}$ & 25 \\
\hline Flexural Strength at $900^{\circ} \mathrm{C}$ & $\mathrm{MPa}$ & 45 \\
\hline Flexural Strength upon 10 Spalling Cycle $\left(\mathrm{RT}\right.$ to $\left.850^{\circ} \mathrm{C}\right)$ & $\mathrm{MPa}$ & 25 \\
\hline Cold Compressive Strength at RT & $\mathrm{MPa}$ & 250 \\
\hline Thermal Conductivity at $\mathrm{RT}$ & $\mathrm{W} / \mathrm{m} / \mathrm{K}$ & 0.75 \\
\hline Thermal Conductivity at $950^{\circ} \mathrm{C}$ & $\mathrm{W} / \mathrm{m} / \mathrm{K}$ & 1.50 \\
\hline Thermal Shock Resistance $\left(950^{\circ} \mathrm{C}\right.$ to water quenching at RT) & $\mathrm{Cycles}$ & 30 (minimum) \\
\hline
\end{tabular}

$* \mathrm{RT}=25^{\circ} \mathrm{C}$

Table 2. Benefits to the user for CUMITHERM ${ }^{\circledR}$ products

\begin{tabular}{|c|c|}
\hline Pain-points for User Industry & CUMITHERM $^{\circledR}$ Benefits \\
\hline Thermal shock in application $\&$ hence low life & $\begin{array}{l}\text { Enhanced thermal shock resistance due the } \\
\text { dimensional stability attributed to zero-thermal } \\
\text { expansion coefficient - Improved life of components/ } \\
\text { equipment }\end{array}$ \\
\hline $\begin{array}{l}\text { Wettability of parts in touch with molten metal } \\
\text { surface - hence more down time \& low plant } \\
\text { efficiency }\end{array}$ & $\begin{array}{l}\text { Non-wettability of CUMITHERM }{ }^{\circledR} \text { surface to Molten } \\
\text { Metal - hence reduced downtime \& improved plant } \\
\text { efficiency }\end{array}$ \\
\hline Thermal Loss- hence low energy efficiency & Thermal insulation - better thermal management \\
\hline $\begin{array}{l}\text { Corrosion/Erosion to molten metal in in touch with } \\
\text { molten metal surface }\end{array}$ & $\begin{array}{l}\text { Corrosion \& erosion resistance of CUMITHERM } \\
\text { surface in touch with molten metal - hence maintains } \\
\text { melt purity leading to improved product quality }\end{array}$ \\
\hline
\end{tabular}

conveying \& casting application such as cast houses in primary casting and foundries. The salient features of CUMITHERM ${ }^{\circledR}$ products \& key benefits to the user industry are discussed later in Table 2.

\section{Thermal properties of CUMITHERM ${ }^{\circledR}$}

In CUMITHERM ${ }^{\circledR}$, we use certain proprietary additives to prevent the reverse reaction \& hence decomposition of aluminium titanate phase. The decomposition into aluminium and titanate would generate the thermal mismatch between alumina/titania and aluminium titanate leading to crack development into final product. As mentioned previously, because of thermal hysteresis created from thermal anisotropy, the micros-fissures are present within the CUMITHERM ${ }^{\circledR}$ microstructure.

The area of hysteresis (Fig. 4a) in thermal expansion curves is proportional to micro-fissures density [12]. As seen in the curve, these micro-fissures get healed during heating of the reaction sintered product rendering it to a zero/negative expansion ceramic material.

$$
-470-
$$




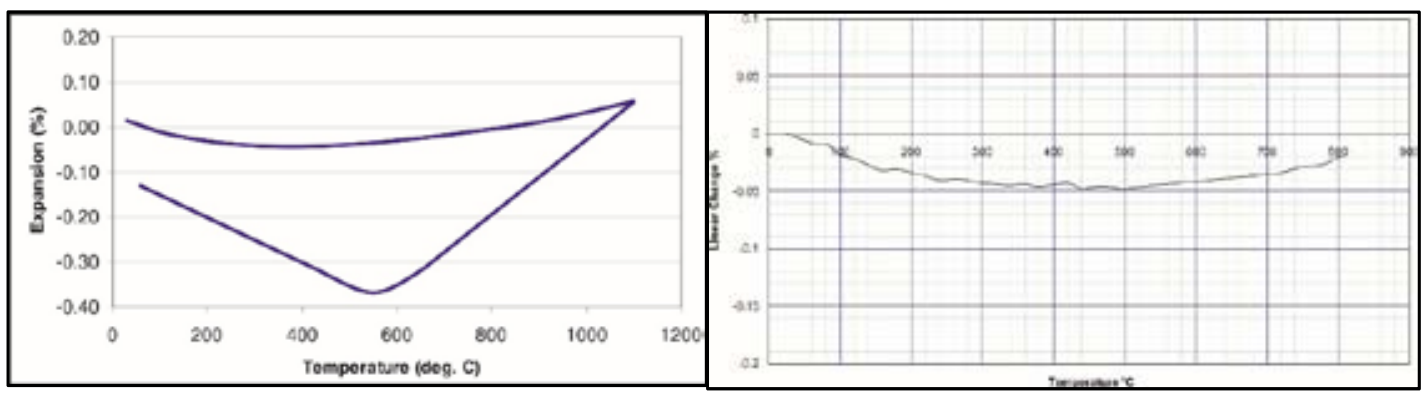

Fig. 4. a) Thermal Hysteresis Curve and b) Thermal Expansion Curve of CUMITHERM ${ }^{\circledR}$

Upon heating, the micro-fissures accommodate further expansion leading to apparent dimensional stability and hence near-zero/negative coefficient of thermal expansion for aluminium titanate products as can be seen in Fig. 4b.

Primarily near-zero thermal expansion coupled with other properties (equation 2) [11] make it a wonderful candidate for thermal shock resistance (TSR).

$$
T S R=\frac{\left(\lambda * \sigma_{B}\right)}{(\alpha * E)}
$$

Where $\sigma_{B}=$ Mean Bending Strength; $\lambda=$ Thermal Conductivity; $\alpha=$ Coefficient of Thermal Expansion; $E=$ Modulus of Elasticity

\section{Mechanical properties of CUMITHERM ${ }^{\circledR}$}

Again, due to the presence of micro-fissures, the flexural strength of aluminium titanate is low. However, the flexural strength increases with increase in temperature which is contrary to other materials. The reason for increase in flexural strength is due to the closure of micro-fissures at higher temperature and hence requires higher stress to propagate the crack into critical crack length leading to fracture. In CUMITHERM ${ }^{\circledR}$ the lower flexural strength at room temperature has been addressed through the usages of proper sintering aids and it has been improved to about $250 \mathrm{~kg} / \mathrm{cm}^{2}$ at room temperature and which increases to $450 \mathrm{~kg} / \mathrm{cm}^{2}$ at $850{ }^{\circ} \mathrm{C}$. Again the compressive strength of CUMITHERM ${ }^{\circledR}$ is very high $\left(3500 \mathrm{~kg} / \mathrm{cm}^{2}\right)$ and is in line with typical properties of ceramic material. The high strength of the CUMITHERM ${ }^{\circledR}$ ceramic is attributed to the proprietary unique formulation and the sintering profile. The Flexural Strength of CUMITHERM ${ }^{\circledR}$ is higher than that reported by JlangLan, et al [9].

The micro-fissures tend to get closed under compression and that is why CUMITHERM ${ }^{\circledR}$ is stronger under compression but relatively weaker under tension/bending in line with conventional ceramic properties. The presence of micro-fissures in aluminium titanate makes it an exceptional thermal insulator.

\section{Hg Porosimetry}

CUMITHERM ${ }^{\circledR}$ has a bimodal porosity distribution as seen from the Hg porosimetry plot which characterizes the densification and hence microstructureof CUMITHERM ${ }^{\circledR}$ products. 


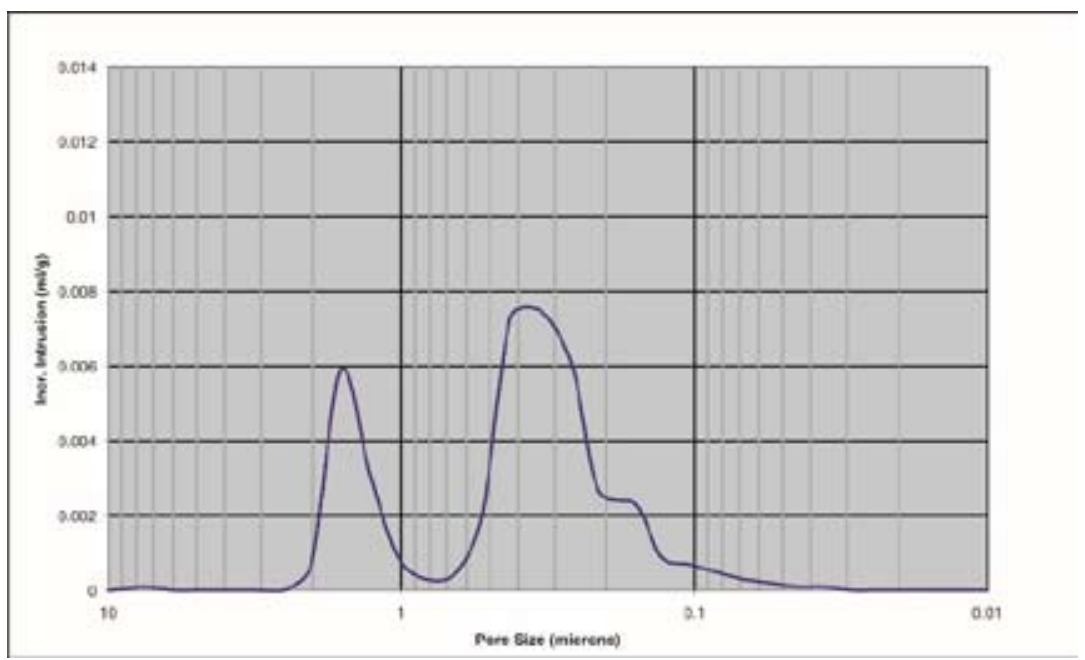

Fig. 5. Hg Porosimetry Plot

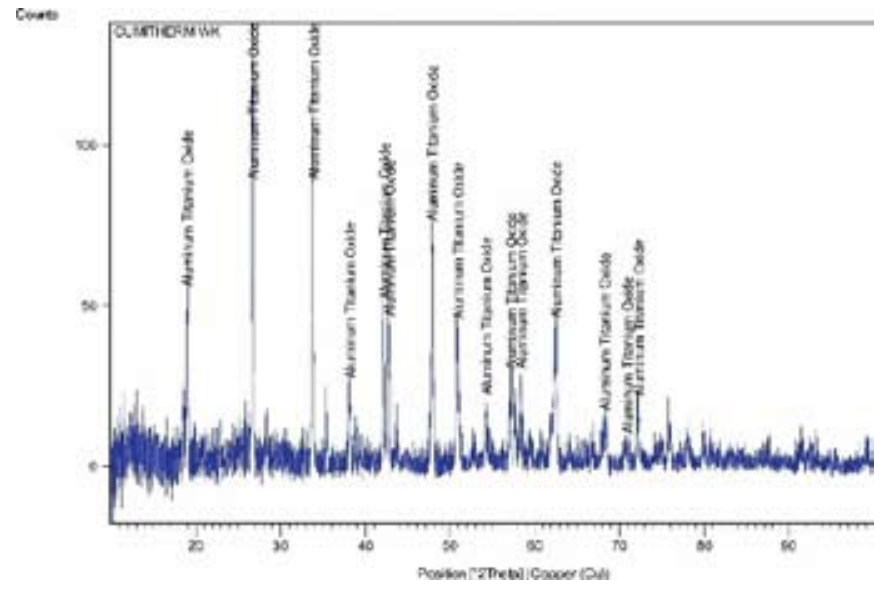

Fig. 6. XRD Pattern for CUMITHERM ${ }^{\circledR}$

\section{Phase Analysis}

As can be seen in Fig. 6. the XRD pattern all the high intensity peaks are attributed to the Aluminium Titanate (AT) Phase which indicates a phase pure crystalline structure. Sintering at a high temperature for sufficient time promotes crystallinity of the AT phase as is evident from the XRD patterns.

\section{Microstructure Analysis}

For CUMITHERM, closely packed and apparent pores could hardly be seen, but some innercrystal pores are formed (Fig. 7 (b)). It is obvious that the high bulk density of $3.25 \mathrm{~g} / \mathrm{cm}^{3}$ and strength of $25 \mathrm{MPa}$ are correlative with the decrease of apparent pores. Moreover, inner-crystal pores are of benefit to deactivate the main crackle and ease the stress concentration on the tip of main crackle or split the main crackle, which enhance the material strength accordingly. 


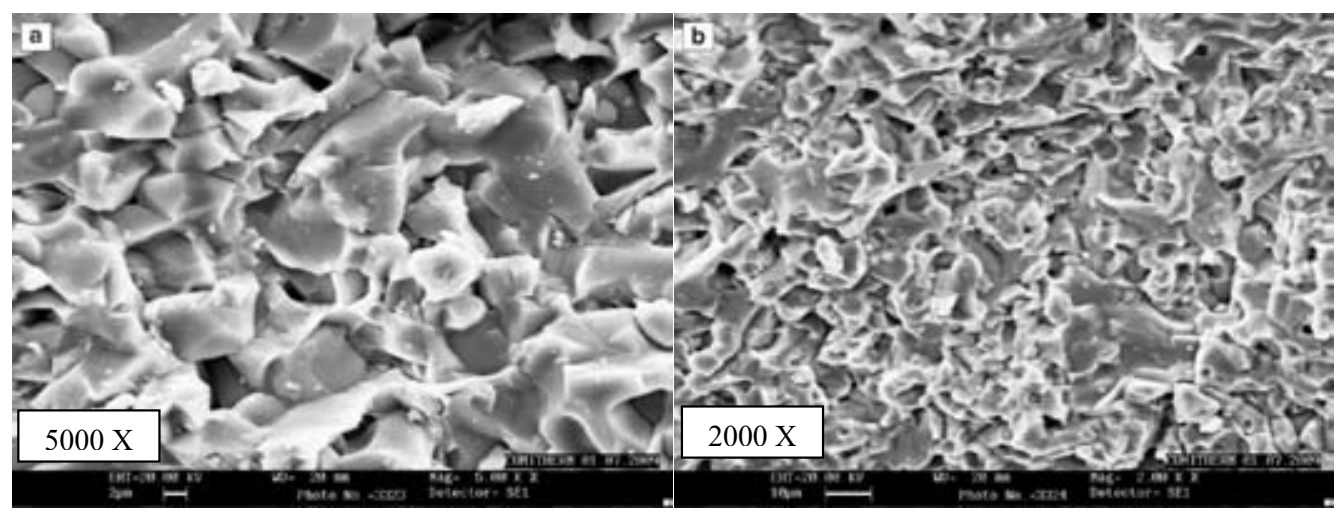

Fig. 7. Microstructures of fracture surface of CUMITHERM ${ }^{\circledR}$

\section{Applications}

\section{Primary Metal Processing Industry:}

In primary metal processing industry, aluminium metal is produced in the form of ingot, billet, slab by smelting aluminium metal produced by Hall-Héroult process. Few of the typical applications are mentioned below:

- Launders:Launders are lined with CUMITHERM ${ }^{\circledR}$, used for the transfer of molten aluminium metal for continuous casting, billet casting and ingot casting. The choice of the launder cross-section is made on the basis of the casting speed of the system to ensure an optimal combination of turbulence-free flow of metal in the launder and minimized heat loss. The use of launder helps to improve thermal efficiency (being insulator) and to reduce the maintenance downtime preventing the metal freeze off. It also helps to maintain metal purity due to its excellent wear and corrosion resistance against molten non-ferrous molten metal.

- Furnace Lining: Again due to the aforesaid properties CUMITHERM ${ }^{\circledR}$ bricks-lined smelting furnace has many advantages over conventional castable/refractory brick-lined furnace. CUMI has capability to pre-engineer bricks required to develop suiTable contour of the smelting furnace.

- Ceramic Sleeves/Spouts: The ceramic spouts are used to transfer molten metal from one launder to another positioned at different height level and also to transfer molten metal from launder to tundish for subsequent casting operation. CUMITHERM ${ }^{\circledR}$ spout/sleeve is most suiTable to perform with enhanced life and trouble-free maintenance due to its unique properties as mentioned earlier.

- Skimmer Plate: CUMITHERM ${ }^{\circledR}$ skimmer plate is placed in tundish\& is used to filter molten metal from any impurity prior to casting operation.

- Ceramic Thimbles:CUMITHERM ${ }^{\circledR}$ thimble is one of the major application for billet casting due to its excellent erosion and corrosion resistance as well as its non-wettability to molten metal.

- Spouts, Control Pin and Retainer Ring: CUMITHERM ${ }^{\circledR}$ finds its extensive application in spout, control pin \& retainer rings for ingot casting process. 


\section{Foundries}

- Pressure Die Casting: CUMITHERM ${ }^{\circledR}$ tube is used to convey molten metal for die casting process, The molten aluminium metal/alloys are pressurized to flow through CUMITHERM $^{\circledR}$ dosing tube (for high-pressure die casting, HPDC [Fig. 9 (a)] in StrikoWestofen/Krown furnace) and riser tubes (for low pressure die casting, LPDC [Fig. 9 (b)]) to mould cavity for subsequent forming process. In dosing and riser tube, the heart of respective process, the hot molten metal passes through it in every stroke. Therefore, thermal shock resistance and non-wettability along with thermal insulation property are the key requirements of this line of product. CUMITHERM ${ }^{\circledR}$ tubes provide long life, thermal efficiency and low maintenance due to its unique properties, Sprue bushes, Connectors, Feeder box can also be made with CUMITHERM ${ }^{\circledR}$ material.

- Tapping Plug, Tapping Ring \& Insulating Ring: In melting tower furnace CUMITHERM ${ }^{\circledR}$ material are being used as tapping plug and ring as well as insulation ring to tap the molten metal to moving ladle from the tower furnace.

\section{Induction Heating Applications}

- Induction Ceramic Tube:CUMITHERM ${ }^{\circledR}$ tube is used to convey the job prior to hot forging application. Usually, the cycle time of heating is few seconds and the tube undergoes tremendous thermal stress due to repeated heating. The thermal shock resistance along with insulation
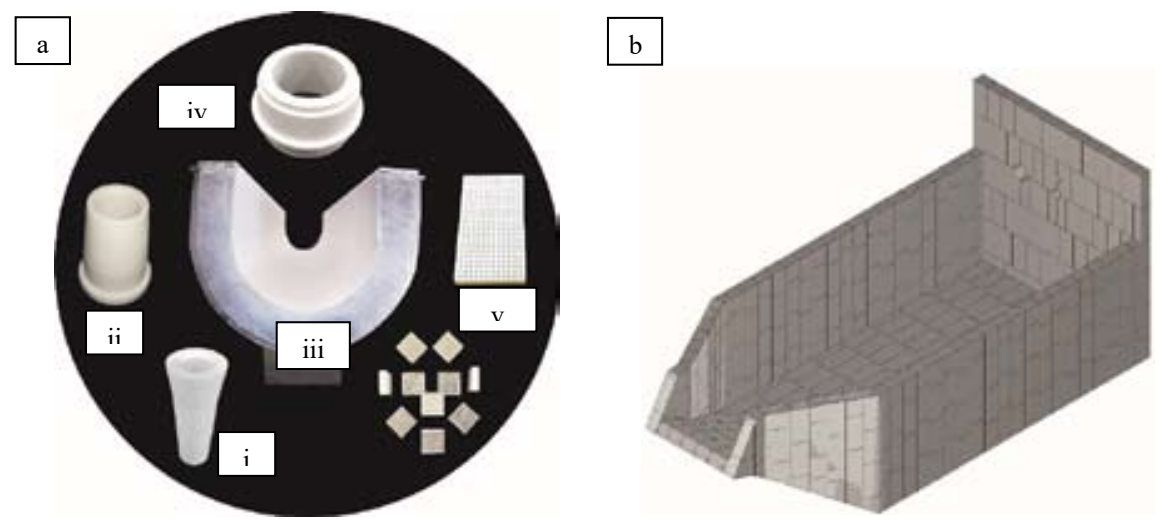

Fig. 8. CUMITHERM ${ }^{\circledR}$ products for a) Primary Casting, (i) Spout, (ii) Sleeve, (iii) Launder, (iv) Thimble, (v) Skimmer plate and filtersand b) Smelting Furnace

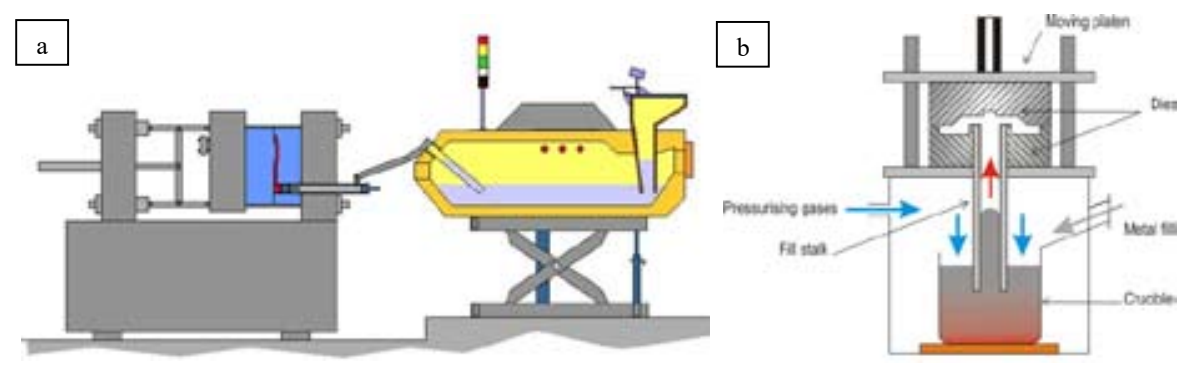

Fig. 9. High pressure die casting, HPDC (left) and Low pressure die casting, LPDC process (right) 
properties make it a perfect choice for such application. The application temperature is much higher $\left(1200\right.$ to $\left.1450^{\circ} \mathrm{C}\right)$ and such higher.

- Brazing Fixtures \& Forceps: Brazing fixtures and forceps are used in metal to metal brazing process. High thermal shock resistance and high strength (at high temperature) of CUMITHERM material suit the brazing application where heating and brazing to be completed in few seconds.

\section{Other Applications}

Spray Nozzles: The spray nozzles are used in the atomization process for preparation of high quality metal powders from non-ferrous molten metals. High thermal shock resistance and non-wettability (with non-ferrous metals)characteristics of CUMITHERM ${ }^{\circledR}$ are perfectto suit this application.

\section{Conclusion}

CUMITHERM $^{\circledR}$ as designed and developed by CUMI - IC is the best in class reaction sintered aluminium titanate material both in terms of properties achieved and for target applications. The formulation is so designed to achieve excellent mechanical and thermal properties as explained above. Phase and microstructure analysis shown above confirms the typical characteristics of aluminium titanate. The excellent thermal performance of CUMITHERM ${ }^{\circledR}$ is also evident from the thermal expansion and thermal hysteresis curves. Thehigh bulk density of $3.25 \mathrm{~g} / \mathrm{cm}^{3}$ and strength of 25 $\mathrm{MPa}$ are correlative with the microstructure and also with bimodal porosity distribution as seen in the Hg porosimetry. The excellent mechanical and thermal properties of CUMITHERM ${ }^{\circledR}$ make it the most suiTable candidate for diversified applications such asmolten metal handling in primary metal processing industries, foundriesas well as atomization nozzles for non-ferrous metal powder

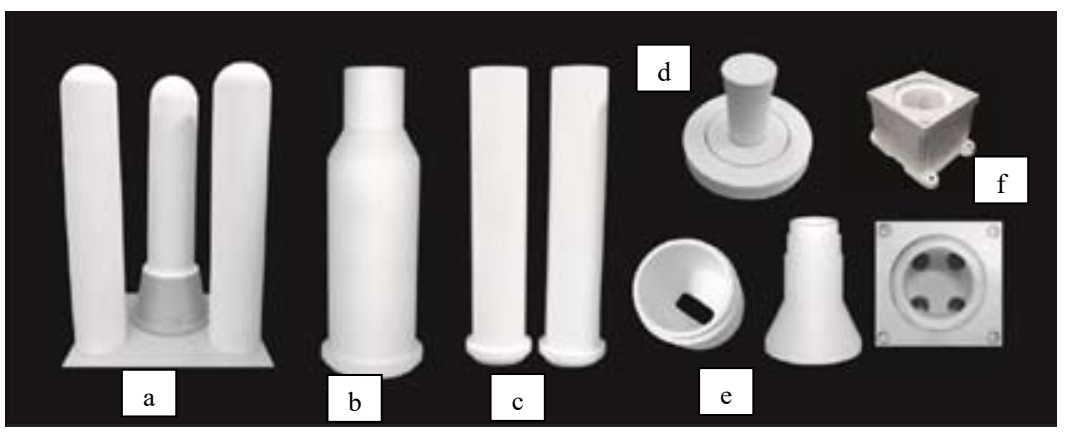

Fig. 10. CUMITHERM ${ }^{\circledR}$ products a) Dosing tube, b) LPS tube, c) Riser tube, d) Tapping plug and ring, e) Sprue bushes and f) Feeder box assembly

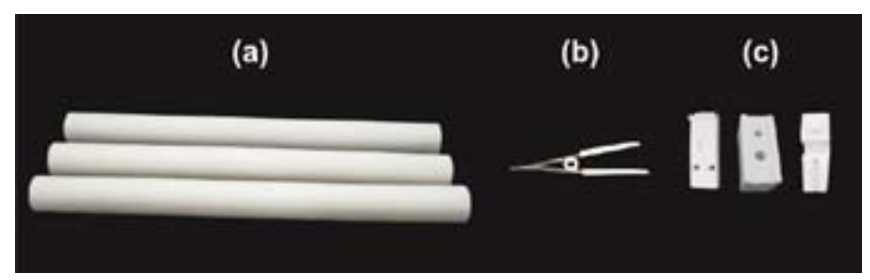

Fig. 11. CUMITHERM ${ }^{\circledR}$ products (a) Ceramic tube, (b) Forceps and (c)Brazing fixtures 
preparation. Followings are the key benefits to the users of CUMITHERM ${ }^{\circledR}$ products as compared to conventional products that customers might be using now.

\section{References}

Morosin B.,Lynch R. W. Structure studies on $\mathrm{Al}_{2} \mathrm{TiO}_{5}$ at room temperature and at $600{ }^{\circ} \mathrm{C}$. Acta Crystallographica. B: Structural science, crystal engineering and materials1972. Vol.28, P. 10401044.

SkalaR. D., Li D., Low I.M. Diffraction, structure and phase stability studies on aluminiumtitanate. Journal of the European Ceramic Society 2009. Vol. 29 (1), P. 67-75.

Bayer G. Thermal expansion characteristics and stability of pseudobrookite-type compounds Me305. Journal of the Less-Common Metals1971. Vol. 24. P. 129138.

Naghizadeh R., Rezaie H.R., Golestani-fard F.The influence of composition, cooling rate and atmosphere on the synthesis and thermal stability of aluminum titanate. Materials Science and Engineering: B 2009. Vol. 157, P. 20-25.

Korim T. Effect of $\mathrm{Mg} 2+-$ and $\mathrm{Fe} 3+$-ions on formation mechanism of aluminiumtitanate. Ceramics International 2009. Vol. 35 (4). P. 1671-1675.

LinpingZh.The study of aluminiumtitanate by solid statethermal shock resistance of AT ceramics due to fabrication and its modifying. Journal of Ceramics 2009. Vol. 30(1). P. 79-84.

Shi C.G.,Low I.M.Effect of Spodumene Additions on the Sintering and Densification of Aluminum Titanate.Materials Research Bulletin 1998. Vol. 33 (6). P. 817-824.

Jiang L.,Chen X.-Y.,Han G.-M., Meng Y. Effect of additives on properties of aluminiumtitanate ceramics. Transactions of Nonferrous Metals Society of China 2011. Vol. 21 (7), P. 1574-1579.

Hume-Rothery W. Atomic diameters, atomic volumes and solid solubility relations in alloys. Acta Metallurgica 1966. Vol.14.P. 17-20.

KingeryW.D. Factors Affecting Thermal Stress Resistance of Ceramic Materials. Journal of the American Ceramic Society 1955. Vol. 38 P. 3-15.

Lingenberg W.Werkstoffeigenschaften von A12TiO5 unterbesondererBerücksichtigung von Bildungs und Zerfallsreaktionen. Disertation. TU Clausthal: 1985. 